\title{
On Some Fiscal Decisions of Caligula and Vespasian
}

The period of the Principate was a time of urgent search for sources of income. It all started with Augustus, who introduced an extensive reform of public finances. These changes, partly connected to the aerarium militare, a treasury accumulating means for the severance and payments of veterans, established in 6 A.D., included mainly the introduction of a number of new payments, such as the legacy tax (vicesima hereditatum), or sales taxes (centesima rerum venalium and quinta et vicesima venalium mancipiorum $)^{1}$.

The successors of Augustus were also troubled by constant financial difficulties. These resulted not only from the wastefulness of some of them, but also from the forming status of the Caesarean treasury (fiscus caesaris), supplied obviously from diverse sources, but at the same time in a gradual manner overtaking public expenses, especially these concerning the army and the maintenance of the capital ${ }^{2}$. They tried to resolve these problems in various ways, the easiest of which was to lay new public tributes. The $1^{\text {st }}$ century A.D. does not lack these, although most of them, as it seems, didn't last long. The sources providing information here are scarce; what is more, all of them are literary texts by Josephus, Suetonius, and Cassius Dio. Such sources usually provide fragmentary and inaccurate technical data, which makes it much more difficult, often impossible, to reconstruct the form of a tax, or even to determine its rate. These accounts, however, indicate first and foremost, that the rulers were determined to look for sources of income wherever they could hope to find them.

It seems that Caligula was particularly active in this respect. Suetonius provides us with a spectacular description of his endeavors, stating at the beginning of his account, that the ruler levied new and unheard of taxes... and there was no class of

\footnotetext{
1 Cf. A. Pikulska-Radomska, Centesima rerum venalium i quinta et vicesima venalium mancipiorum: podatki od transakcji sprzedaży, [in:] O prawie i jego dziejach ksiegi dwie. Studia ofiarowane Profesorowi Adamowi Lityńskiemu w czterdziestolecie pracy naukowej i siedemdziesięciolecie urodzin, vol. I, BiałystokKatowice 2010, p. 101-105.

2 Cf. F. Millar, The Fiscus in the First Two Centuries, JRS 53, 1963, p. 29-42; P. Krajewski, Finanse publiczne, [in:] Rzymskie prawo publiczne, ed. B. Sitek, P. Krajewski, Olsztyn 2004, p. 109-123, esp. p. 109.
} 
commodities or men on which he did not impose some form of tariff3. Cassius Dio makes a similar observation ${ }^{4}$.

Suetonius mentions such new taxes as:

- a 2,5 per cent lawsuit tax (quadragesima);

- a fee on groceries sold in Rome;

- a prostitute tax amounting to the payment obtained from one client;

- a porter tax amounting to 12,5 per cent of their daily income (pars octava).

Cassius Dio confirms the first three, and mentions additionally a tavern tax, craftsmen tax, as well as a tax on the income from the work of wage-earning slaves. These lists do not necessarily contradict each other; namely, it is often assumed that the tavern tax Cassius mentions may be connected to Suetonius' grocery tax, and the wage-earning slaves tax is nothing else but the tribute on porters' income ${ }^{5}$. Facing the lack of further sources, we must leave the problem unsolved for now.

The circumstances under which these taxes were introduced are worthwhile. The accounts of historians differ; however, it is certain that these measures met with obstacles. Primarily, the ruler was confronted with accusations concerning the improper form of the publication of the lex instituting these taxes. Having proclaimed the introduction of taxation, Caligula initially waived disclosing the content of the new law to the public. The people became resentful, as due to the ignorance of its substance many broke the new law and had to face the consequences. According to Suetonius and Cassius Dio, influenced by the protests, the Emperor had the law posted up, but in a very narrow place and in excessively small letters, to prevent

\footnotetext{
3 Suetonius, De vita caesarum / The Lives of the Caesars, IV, 40, trans. J.C. Rolfe, London-New York 1914 (cetera: Suetonius): Vectigalia nova atque inaudita primum per publicanos, deinde, quia lucrum exuberabat, per centuriones tribunosque praetorianos exercuit, nullo rerum aut hominum genere omisso, cui non tributi aliquid imponeret. Pro edulibus, quae tota urbe venirent, certum statumque exigebatur; pro litibus ac iudiciis ubicumque conceptis quadragesima summae, de qua litigaretur, nec sine poena, si quis composuisse vel donasse negotium convinceretur; ex gerulorum diurnis quaestibus pars octava; ex capturis prostitutarum quantum quaeque uno concubito mereret; additumque ad caput legis, ut tenerentur publico et quae meretricium quive lenocinium fecissent, nec non et matrimonia obnoxia essent

(He levied new and unheard of taxes, at first through the publicans and then, because their profit was so great, through the centurions and tribunes of the praetorian guard; and there was no class of commodities or men on which he did not impose some form of tariff. On all eatables sold in any part of the city he levied a fixed and definite charge; on lawsuits and legal processes begun anywhere, a fortieth part of the sum involved, providing a penalty in case anyone was found guilty of compromising or abandoning a suit; on the daily wages of porters, an eighth; on the earnings of prostitutes, as much as each received for one embrace; and a clause was added to this chapter of the law, providing that those who had ever been prostitutes or acted as panders should be liable to this public tax, and that even matrimony should not be exempt).

4 Cassius Dio Cocceianus, Historia Romana, LIX, 28, 8, trans. E. Cary, H.B. Foster, vol. VII, Cambridge 1959 (cetera: Dio CAssius): he was doing all this was also collecting money in most shameful and dreadful ways. One might, indeed, pass over in silence the wares and the taverns, the prostitutes and the courts, the artisans and the wage-earning slaves, and other such sources, from which he collected every conceivable tribute.

5 Cf. S. GüNTHER, „Vectigalia nervos esse rei publicae”. Die indirekten Steuern in der Römischen Keiserzeit von Augustus bis Diokletian, Wiesbaden 2008, p. 156.
} 
the making of a copy $y^{6}$. The attempt to negotiate a reduction of the tax failed. Josephus ${ }^{7}$ and Cassius Dio speak of bloody riots in a circus, and Josephus even mentions an execution of its leaders.

Also, the method of collection was interesting. Suetonius states that Caligula promptly ceased leasing this practice to publicans, as traditionally accepted, as he assessed their income to be too high. The tax was collected by praetorians instead. Even today we can easily imagine scenes of armed guardsmen pacing through the markets and alleys, collecting the money and certainly showing no mercy to the resisting. a similar account is to be found in Josephus ${ }^{8}$, who, however, refers only to the case of Cassius Chaerea, the praetorian guard. The latter was nominated as the main collector of taxes and other duties, often overdue. The fact that he showed sympathy to debtors caused the Emperor's displeasure, and made him a victim of harassments. His hatred towards the ruler, which resulted from these events, led him to participate in the conspiracy to murder Caligula.

Bearing in mind other proofs of the Emperor's greed, which Suetonius and Cassius Dio describe in their works with barely hidden satisfaction, such as funding a brothel on the Palatine Hill, giving usurious loans, game cheating, perjury, receiving minor offerings from the people and rolling in collected coins ${ }^{9}$, Caligula

6 Suetonius, IV, 41: Eius modi vectigalibus indictis neque propositis, cum per ignorantiam scripturae multa commissa fierent, tandem flagitante populo proposuit quidem legem, sed et minutissimis litteris et angustissimo loco, uti ne cui describere liceret

(When taxes of this kind had been proclaimed, but not published in writing, inasmuch as many offences were committed through ignorance of the letter of the law, he at last, on the urgent demand of the people, had the law posted up, but in a very narrow place and in excessively small letters, to prevent the making of a copy);

Dio Cassius, LIX, 28, 11: But when, after enacting severe laws in regard to the taxes, he inscribed them in exceedingly small letters on a tablet which he then hung up in a high place, so that it should be read by as few as possible and that many through ignorance of what was bidden or forbidden should lay themselves liable to the penalties provided, they straightway rushed together excitedly into the Circus and raised a terrible outcry. Once when the people had come together in the Circus and were objecting to his conduct, he had them slain by the soldiers; after this all kept quiet.

7 Josephus Flavius, Jewish Antiquities, XIX, 1, 4, 25sqq, trans. L.H. Feldman, vol. VIII, Cambridge 1965 (cetera: Josephus, Antiquities).

8 Josephus, Antiquities, XIX, 1, 5, 28.

9 Suetonius, IV, 41: Ac ne quod non manubiarum genus experiretur, lupanar in Palatio constituit, districtisque et instructis pro loci dignitate compluribus cellis, in quibus matronae ingenuique starent, misit circum fora et basilicas nomenculatores ad invitandos ad libidinem iuvenes senesque; praebita advenientibus pecunia faenebris appositique qui nomina palam subnotarent, quasi adiuvantium Caesaris reditus. Ac ne ex lusu quidem aleae compendium spernens plus mendacio atque etiam periurio lucrabatur. Et quondam proximo conlusori demandata vice sua progressus in atrium domus, cum praetereuntis duos equites R. locupletis sine mora corripi confiscarique iussisset, exultans rediit gloriansque numquam se prosperiore alea usum.

(To leave no kind of plunder untried, he opened a brothel in his palace, setting apart a number of rooms and furnishing them to suit the grandeur of the place, where matrons and freeborn youths should stand exposed. Then he sent his pages about the fora and basilicas, to invite young men and old to enjoy themselves, lending money on interest to those who came and having clerks openly take down their names, as contributors to Caesar's revenues. He did not even disdain to make money from play, and to increase his gains by falsehood and even 
proves to have been an extremely covetous man. But wasn't he perhaps just entirely devoted to the idea of gaining fiscal resources?

It is, however, worthwhile to mention that Caligula went down in history, even if not in glory, as a tax-abolishing reformer. In 38 A.D. he revoked centesima rerum venalium, an unpopular, although not particularly high in Roman reality $(0,5$ to 1 per cent) auction sale tax. But it was just the beginning of Caligula's reign... ${ }^{10}$

We know nothing about some of the tributes established by Caligula, apart from the accounts of appointed historians. Thus it is no surprise that these weren't of interest for scholars. The subject of their interest were rather tributes collected from prostitutes, grocery traders, and litigant parties The prostitution tax has already been discussed by Andrzej Sokala ${ }^{11}$; in this paper I will therefore limit myself to a few remarks on the litigation $\operatorname{tax}^{12}$.

Caligula decided that litigant parties, regardless where the litigation was to be settled, were to pay a tax amounting to 2,5 per cent of the value of its subject. As for now, everything seems to fall within an acceptable scope, but the further part of Suetonius' account (Cassius Dio does not mention the details) is troubling. Now, the legislator forbade, under threat of an indefinite, but probably financial penalty, arbitrational agreements and withdrawing from lawsuit. This regulation was doubtlessly very inconvenient for the parties. It could, however, have a side effect: especially in the case of serious litigations, the subject of which had a high value, they would think twice before going to lawsuit at all. In this context it is decisive to establish when exactly the tax was abolished. There exists no conclusive reference in the sources, although Suetonius mentions in his life of Claudius that the latter cancelled all of Caligula's acta ${ }^{13}$. It is, however, known, that the derogation didn't include the prostitute tax or groceries tax. Thus, speculations in the literature appeared suggesting that, quadragesima litium could have been in force until 58 A.D.,

by perjury. Having on one occasion given up his place to the player next to him and gone into the courtyard, he spied two wealthy Roman knights passing by; he ordered them to be seized at once and their property confiscated and came back exultant, boasting that he had never played in better luck);

Dio CAssius, LIX, 28, 9-10: But how could one keep silent about the rooms set apart in the very palace, and the wives of the foremost men as well as the children of the most aristocratic families that he shut up in those rooms and subjected to outrage, using them as a means of milking everybody alike? Some of those who thus contributed to his need did so willingly, but others very much against their will, lest they should be thought to be vexed. The multitude, however, was not greatly displeased by these proceedings, but actually rejoiced with him in his licentiousness and in the fact that he used to throw himself each time on the gold and silver collected from these sources and roll in it.

10 Suetonius, IV, 16: Ducentesimam auctionum Italiae remisit.

11 A. SoKala, Meretrix i jej pozycja w prawie rzymskim, Toruń 1998, p. 78-84.

12 The literature concerning this tax is scarce, the most extensive contribution is: R. CAGNAT, Etude historique sur les impôts indirects chez les Romains jusquaux invasion des barbares, Paris 1882 [repr. Roma 1966], p. 235-236; also cf. M. KASER, Das römische Zivilprozessrecht, München 1966, p. 393, an. 19; M. CAmacho de los Rios, Vectigalia. Contribucion al estudio de los impuestos en Roma, Granada 1995, p. 247-248; a couple of remarks are also to be found in S. GüNTHER, op. cit., p. 159-160.

13 Suetonius, V, 11, 3: Gai quoque etsi acta omnia rescidit. 
i.e. until Nero's reforms, discussed by Tacitus ${ }^{14}$. In his reflections, the historian admittedly mentions the term quadragesima, even in the plural, but it does not necessarily have to refer to the litigation tax, as the reform was directed against illegal income of publicans. Even if we assume that the tax was still in force and it was, just as in Caligula's times, not collected by the publicans, Nero's reform might have excluded it. The second interpretation dates the cancellation of the tax to Galba's times. It rests upon numismatic evidence, especially the fact, that on numerous coins from this period, the inscription quadragesima remissa is to be found ${ }^{15}$. Certainly it could refer to the litigation tax, it was considered doubtful in earlier literature already, and newer studies assume, that the coins indicated the cancellation of another tax, namely quadragesima Galliarum, which was a kind of customs ${ }^{16}$.

It is worthwhile to mention one more famous tribute, established by Vespasian. On various curiosity-lists, one of the top spots is often occupied by the fact that this Roman Emperor introduced a urine tax (vectigal urinae). If this information is in any way commented, the comment is usually mocking. This tradition has clung to Vespasian so fast that even public urinals, installed in Paris at the beginning of the $19^{\text {th }}$ century by the prefect of the department of Seine, count Rambuteau, were dubbed colonnes vespasiennes, or just vespasiennes. It is also the case in Italian (vespasiani) and Romanian (vespasiene).

The tax in question is not a subject of interest of scholars, as the entire knowledge at our command is based on Suetonius' account, repeated nearly literally by Cassius Dio $^{17}$. They both describe a scene which was supposed to happen between

14 Tacitus, Libri ab excessu divi Augusti, XIII, 51, ed. P.K. Huibregtse, vol. I, Groningen 1958 (cetera: TACITUs, Annales): Manet [...] abolitio quadragesimae quinquagesimaeque et quae alia exactionibus inlicitisnomina publicani invenerant. (The annulment, however, of the "fortieth", "fiftieth", and other irregular exactions, for which the publicans had invented titles, is still in force).

${ }_{15}$ Literally quadragens remissae, (quadragens) vma remissa, or quadragensumae remiss - The Roman Imperial Coinage, ed. C.H.V. Sunderland, R.A.G. Carson, vol. I, ed. C.H.V. Sunderland, London 1984, p. $219,225,228,236$ [no. 77-84].

16 Cf. S. GÜNTher, op. cit., p. 160. On quadragesima Galliarum lately: J. FrancE, Quadragesima Galliarum: lorganisation douanière des provinces alpestres, gauloises et germaniques de l'Empire Romain (Irer siècle avant J.-C. - III siècle après J.-C.), Rome 2001.

17 Suetonius, VIII, 23, 3: Reprehendenti filio Tito, quod etiam urinae vectigal commentus esset, pecuniam ex prima pensione admovit ad nares, sciscitans num odore offenderetur; et illo negante: "Atqui", inquit, "elotio est." Nuntiantis legatos decretam ei publice non mediocris summae statuam colosseam, iussit vel continuo ponere, cavam manum ostentans et paratam basim dicens

(When Titus found fault with him for contriving a tax upon public conveniences, he held a piece of money from the first payment to his son's nose, asking whether its odour was offensive to him. When Titus said "No" he replied, "Yet it comes from urine." On the report of a deputation that a colossal statue of great cost had been voted him at public expense, he demanded to have it set up at once, and holding out his open hand, said that the base was ready);

Dio CAssius, LXV, 14: When some persons voted to erect to him a statue costing a million, he held out his hand and said: "Give me the money; this is its pedestal." And to Titus, who expressed his indignation at the tax placed upon public urinals, - one of the new taxes that had been established, - he said, as he picked up some gold pieces that had been realized from this source and showed them to him: "See, my son, if they have any smell." 
the Emperor and his son, Titus. When Titus one day lamented about the repulsive nature of the tax, Vespasian let him smell a couple of coins and asked if he felt any odor. When his son denied, the Emperor claimed that they came from urine. Non olet! It is worth mentioning, that besides the anecdote about the conversation with Titus, both sources include another, concerning the reaction of the Emperor to the news of the initiative to build an expensive statue in his honor. He immediately required from the initiators of the enterprise a part of the financial resources meant to be spent on the figure and, showing them an empty hand, told them that the plinth had already been ready. Both historians mention this anecdote as a proof of the Emperor's greed, but also humor. Suetonius, condemning Vespasian's features, admits that when he came to power, the treasury had been in a pitiful condition. He didn't miss any opportunity to replenish it, and he made good use of every penny gained in a bad way ${ }^{18}$.

The problem concerns, of course, maintaining cleanliness in the city. The production of waste was enormous, though, as Olivia Robinson rightly asserted, the Romans had one great advantage over us: they knew no plastic and they did not wrap up gifts ${ }^{19}$. Everything they produced was nearly immediately processed ${ }^{20}$.

18 Suetonius, VIII, 16: Sola est, in qua merito culpetur, pecuniae cupiditas. Non enim contentus omissa sub Galba vectigalia revocasse, novas et gravia addidisse, auxisse tributa provinciis, nonnullis et duplicasse, negotiationem quoque vel privato pudendas propalam exercuit, coemendo quaedam tantum ut pluris postea distraheret. Ne candidatis quidem honores reisve tam innoxiis quam nocentibus absolutiones venditare cunctatus est. Creditur etiam procuratorum rapacissimus quemque ad ampliora officia ex industria solitus promovere, quo locupletiores mox condemnaret; quibus quidem volgo pro spongiis dicebatur uti, quod quasi et siccos madefaceret et exprimeret umentis. Quidam natura cupidissimum tradunt, idque exprobratum ei a sene bubulco, qui negata sibi gratuita libertate, quam imperium adeptum suppliciter orabat, proclamaverit, vulpem pilum mutare, non mores. Sunt contra qui opinentur ad manubias et rapinas necessitate compulsum summa aerarii fiscique inopia, de qua testificatus sit initio statim principatus, professus quadringenties milies opus esse, ut res p. stare posset. Quod et veri similius videtur, quando et male partis optime usus est

(The only thing for which he can fairly be censured was his love of money. For not content with reviving the imposts which had been repealed under Galba, he added new and heavy burdens, increasing the amount of tribute paid by the provinces, in some cases actually doubling it, and quite openly carrying on traffic which would be shameful even for a man in private life; for he would buy up certain commodities merely in order to distribute them at a profit. He made no bones of selling offices to candidates and acquittals to men under prosecution, whether innocent or guilty. He is even believed to have had the habit of designedly advancing the most rapacious of his procurators to higher posts, that they might be the richer when he later condemned them; in fact, it was common talk that he used these men as sponges, because he, so to speak, soaked them when they were dry and squeezed them when they were wet. Some say that he was naturally covetous and was taunted with it by an old herdsman of his, who on being forced to pay for the freedom for which he earnestly begged Vespasian when he became emperor, cried: "The fox changes his fur, but not his nature." Others on the contrary believe that he was driven by necessity to raise money by spoliation and robbery because of the desperate state of the treasury and the privy purse; to which he bore witness at the very beginning of his reign by declaring that forty thousand millions were needed to set the State upright. This latter view seems the more probable, since he made the best use of his gains, ill-gotten though they were).

19 O. Robinson, Ancient Rome: City Planning and Administration, s.l. 2003, p. 106.

${ }^{20}$ C. Courrier, Rome et ses déchets: salubrité et insalubrité d'une mégalopole antique, http://pradis. ens-lyon.fr/article.php3?id_article=184 [26 VI 2012]. 
Only a relatively limited number of houses in the city, and certainly not the rental ones, had running water and a sewer system. WC-like installations, with seats above running water, must have been very rare in private buildings. Some houses were equipped with lavatories (latrinae), but most people used boxes, or simply vessels, which slaves subsequently flushed into the gutter or put on waste-removing cars. Public meeting spaces were equipped with latrines (foricae). These were attended and cleaned by foricarii, employees of companies leasing cleaning services. Despite the fact that the lease wasn't low, and the delay in payment resulted in very high interest ${ }^{21}$, this business was, just as in the epochs to follow, very profitable. There also existed public urinals - large, conveniently cut short vessels (dolia curta). They were placed in side alleys or street corners and emptied regularly by foricarii. The urine gained was sold to tanners and fullers, to whom it was a valuable resource for processing leather and clean wool fabric, due to its high content of ammonia. Until now, all authors commenting on this issue agree. Adolphe Duraeu de la Malle ${ }^{22}$ is of the opinion, that entrepreneurs charged a fee for using public toilets and assumes this to be Vespasian's tax. In opposition to that, Olivia Robinson ${ }^{23}$ and Andreas Wacke ${ }^{24}$ mention the urine tax on the margin of their studies and claim that it was the usage of the urine that was taxed, and the tax was paid by entrepreneurs utilizing the urine.

In view of the scarce source material, one cannot be certain whether it was a tax or some other sort of tribute. The argument that Suetonius used the term vectigal when telling this story for the first time is not decisive bearing in mind the fuzziness of the Roman fiscal terminology. Additionally, literary texts are in particular not to be taken word-for-word in this regard. Vectigal urinae might just as well have been a regular tax on a business activity, in this case on running a fulling mill or a tannery, just the same as in case of porters or prostitutes (if we assume the theory, that in case of the latter there existed regularly upgraded registers, which is only partly justified). It might also have been a fee charged on the basis of a public contract with an entrepreneur leasing cleaning services. Or maybe just a fee for using public toilets?

In the times of the early Empire, many tributes were often justified spontaneously, without a deeper analysis. Thus, some of them did not last long which is not surprising. The fate of the taxes mentioned above reaffirms the thesis that in spite of searching for various solutions, the state of Rome never had an organized tax system which would have been integrated into the economy, or even provided means for public expenses. It was rather a chaotic thicket of particular, often re-

\footnotetext{
${ }^{21}$ Digesta XXII, 1, 17, 5, rec. T. Mommsen, [in:] Corpus Iuris Civilis, vol. I, ${ }^{10}$ Berolini 1906 (cetera: Dig.): Fiscus ex suis contractibus usuras non dat, sed ipse accipit: ut solet a foricariis, qui tardius pecuniam inferunt, item ex vectigalibus. Cum autem in loco privati successit, etiam dare solet. (As it shows, interest was collected even from the heirs of the debtor).

${ }^{22}$ M. Dureau de la Malle, Economie politique des Romains, Paris 1840, p. 481.

${ }^{23}$ O. Robinson, op. cit., p. 105.

24 A. WACKe, Protection of the Environment in Roman Law?, RLT 1, 2002, p. 1-24, esp. p. 8.
} 
gional taxes, which could not serve as means for controlling economic processes ${ }^{25}$. This also has to apply to the famous portorium, a diversified transport fee, often inaccurately identified with customs. It was a tremendous source of income, but the idea to use it for protection of the home market controlling the flow of trades and services or influencing the consumption had not yet been invented.

\begin{abstract}
The history of the Roman Empire is a history of continuously looking for new sources of state revenues. Numerous public loads, spontaneously created during the early Empire, without any deeper analysis, created a disordered mess of particular and curious taxes rather than a centralized system as an instrument of controlling economic processes. The tax decisions of the emperors mentioned in the title, in spite of having a significant influence on the state treasury, were, in fact, of the same disordered nature.
\end{abstract}

\author{
Anna Pikulska-Radomska \\ Katedra Prawa Rzymskiego \\ Wydział Prawa i Administracji \\ Uniwersytet Łódzki \\ ul. S. Kopcińskiego 8/12 \\ 90-232 Łódź, Polska \\ apikulska@wpia.uni.lodz.pl
}

${ }^{25}$ B. D. Shaw, Roman Taxation, [in:] Civilization of the ancient Mediterranean: Greece and Rome, ed. M. Grant, R. Kitzinger, New York 1988, p. 809-810; P. Krajewski, op. cit., p. 109. 